\title{
Analisis Faktor yang Mempengaruhi Variabilitas Nutrisi dan Kontaminasi Mikotoksin pada Bahan Baku Jagung di Sumatera Utara
}

\section{(VARIABILITY ANALYSIS OF FACTORS AFFECTING NUTRITION AND MYCOTOXIN CONTAMINATION IN RAW CORN IN NORTH SUMATRA)}

\author{
Mahyuzar*, Ma'ruf Tafsin, Simon P. Ginting \\ Program Studi Ilmu Peternakan, Program Pascasarjana Fakultas Pertanian, Universitas \\ Sumatera Utara. Jl. Prof. A. Sofyan No.3, Kampus USU, Medan Sumatra Utara, 20155. \\ *Email: mag.ilmupeternakan@gmail.com;drh.yuzar@gmail.com
}

\begin{abstract}
Abstrak
Tujuan penelitian ini adalah untuk mengetahui faktor yang mempengaruhi variabilitas nutrisi dan kontaminasi mikotoksin pada bahan baku jagung di Sumatera Utara dengan memperhatikan tingkat keeratan hubungan antara variable bebas (varietas jagung, lahan tanam, ketinggian, kelembaban relatif, sumber pengeringan, lama penyimpanan, dan tempat penyimpanan) dengan masing-masing variabel terikat (kadar air, kadar protein kasar, kadar lemak kasar, kadar serat kasar, aflatoksin, fumonisin, dan zearalenone). Dari 5 kabupaten terilih di Sumatera Utara, sebanyak 45 orang pedagang, 30 orang pengumpul dan 30 orang pedagang jagung diwawancarai serta sebanyak sebanyak 105 sampel jagung yang berasal dari petani, pedagang dan pengepul jagung pada penelitian ini. Sampel diuji kadar air, kadar protein kasar, kadar lemak kasar, serat kasar, kandungan aflatoksin, fumonisin dan zearalenone. Pengujian kandungan aflatoksin, fumonisin dan zearalenone menggunakan metode LFIA (Lateral Flow Immunochromatic Assay). Analisa statistik dilakukan dengan metode analisa korelasi dan regresi menggunakan SPSS versi 21.0. Hasil penelitian menunjukkan bahwa faktor ketinggian berpengaruh signifikan terhadap kadar air dan serat kasar sedangkan lama penyimpanan mempengaruhi kadar air. Kadar protein kasar dan lemak kasar tidak dipengaruhi oleh variabel bebas manapun. Pada kontaminasi mikotoksin, faktor kelembaban relatif berpengaruh signifikan terhadap kandungan aflatoksin dan fumonisin sedangkan lama penyimpanan berpengaruh signifikan terhadap kandungan aflatoksin. Namun, kandungan zearalenone tidak dipengaruhi oleh variable bebas manapun.
\end{abstract}

Kata kunci: kadar air; kadar protein kasar; kadar lemak kasar; kadar serat kasar; aflatoksin; fumonisin; zearalenone.

\begin{abstract}
The purpose of this study was to determine factors that influence nutritional variability and mycotoxin contamination in corn as raw materials in North Sumatra by observed the correlation between independent variables (corn varieties, planting land, elevation, relative humidity, source of drying, storage time, and storage area) with each dependent variables (the level of moisture, crude protein, crude fat, crude fiber, aflatoxin, fumonisin, and zearalenone). From 5 chosen districts in North Sumatra, we interviewed 45 corn farmers, 30 corn traders, and 30 corn collectors and we also tested 105 corn samples from them. Samples were tested for moisture level $t$, crude protein level, crude fat level, crude fiber level, aflatoxin, fumonisin, and zearalenone. Aflatoxin, fumonisin, and zearalenone level test used the LFIA (Lateral Flow Immunochromatic Assay) method. Statistic analyzed by correlation and regression by using SPSS version 21.0. The results showed that the elevation factor had a significant effect on moisture and crude fiber level and storage time had a significant effect on water content. But none of the crude protein and crude fat levels were affected by any independent variable. In mycotoxin contamination, relative humidity factor had a significant effect on aflatoxin and fumonisin level, storage time had a significant effect on the aflatoxin level but zearalenone was not affected by any independent variable.
\end{abstract}

Keywords: water level; crude protein level; crude fat level; crude fiber level; aflatoxin; fumonisin; zearalenone. 


\section{PENDAHULUAN}

Salah satu sektor usaha peternakan yang tengah marak berkembang di sumatera utara adalah peternakan ayam. Kestabilan produksi ternak ayam baik itu broiler maupun petelur bahkan ayam breeder merupakan tantangan tersendiri di Provinsi Sumatera Utara dimana faktor biosekuriti masih menjadi kendala utama (Ilhami dan Pratiwi, 2018). Kejadian penurunan produksi telur atau keterlambatan pertumbuhan broiler sering terjadi dalam usaha peternakan ayam. Peternak ayam cenderung tidak mampu mencari penyebab hal tersebut karena ayamnya terlihat sehat dan konsumsi pakannya yang cukup (Hidayat, 2012).

Pakan menjadi komponen terbesar yang perlu dipenuhi untuk kesuksesan usaha peternakan ayam. Dalam komposisi pakan, jagung adalah bahan yang dominan, dan sangat berpengaruh bagi pertumbuhan unggas (Hidayat, 2012). Kualitas nutrisi jagung sangat baik dibandingkan bahan pakan lainnya, karena menghasilkan energi yang tinggi dari kandungan cukup banyak pati (energi metabolisme $3.360 \mathrm{kkal}$ per kilogram, TDN 81,9\%) serat kasar cukup rendah sehingga mudah tercerna $(3,37 \%)$, serta mengandung beta karoten yang penting dalam pembentukan warna kuning telur (Karra, 2003).

Jagung merupakan salah satu komoditas pertanian yang mempunyai masalah pada saat penanganan pascapanen, yang ditandai dengan tingginya kontaminasi kapang, yang menghasilkan mikotoksin (Miskiyah dan Widaningrum, 2008). Mikotoksin yang dominan mengkontaminasi jagung antara lain aflatoksin, zearalenone, deoksinivalenol, fumonisin, dan phenicilic acid (Martindah dan Bahri, 2016). Mikotoksin yang terdapat pada jagung dapat muncul ketika kondisi lingkungan menguntungkan (favourable), dengan kisaran suhu antara $4-40^{\circ} \mathrm{C}$ (optimum pertumbuhan adalah antara $25-32^{\circ} \mathrm{C}$ ), serta pada kadar air (optimum pertumbuhan pada 18\%) dan kelembaban tertentu (optimum pertumbuhan pada kelembaban relatif $85 \%$ atau lebih (Miskiyah dan Widaningrum, 2008). Bila tidak dikendalikan, kandungan mikotoksin pada jagung akan meningkat karena dapat dihasilkan oleh kapang sejak dari masa tanam sampai masa penyimpanan dan didukung sifat mikotoksin yang stabil terhadap lingkungan, dan tidak mudah rusak dengan berbagai pengolahan. Oleh karena itu, perlu dirancang penelitian tentang pengaruh pengaruh varietas, lahan tanam, ketinggian, kelembaban relatif, pengeringan, lama penyimpanan, dan tempat penyimpanan terhadap kualitas nutrisi (kadar air, protein kasar, lemak kasar dan serat kasar) dan kadar mikotoksin (kadar aflatoksin, fumonisin dan zearalenone) dan korelasi antara kandungan nutrisi jagung (kadar air, protein kasar, lemak kasar dan serat kasar) dengan kadar mikotoksinnya (kadar aflatoksin, fumonisin dan zearalenone).

\section{METODE PENELITIAN}

\section{Rancangan penelitian}

Penelitianakan dilakukan di Laboratorium Fakultas Peternakan Universitas Sumatera Utara dan Sahabat Laboratorium, Medan pada Februari hingga Oktober 2018. Penelitian ini menggunakan metode survey melalui pengambilan sampel pada lokasi secara langsung untuk mengidentifikasi jenis mikotoksin pada bahan baku jagung. Lokasi pengambilan sampel bahan baku jagung ditentukan dengan cara sengaja atau dengan metode purposive sampling (random sampling) terhadap bahan baku jagung dari beberapa lokasi di provinsi Sumatera Utara. Pengumpulan data dan informasi yang diperoleh dari petani, pedagang dan pengumpul dilakukan dengan menggunakan kuesioner. Data dan informasi yang kumpulan mencakup antara lain lokasi cara pemanenan dan proses penanganan jagung pasca panen, aspek mutu, dan jalur tataniaga dan pemasaran. 


\section{Lokasi sampling}

Lokasi pengambilan sampel jagung ditentukan berdasarkan dari sisi luas tanam maupun dari tingkat produksi tertinggi per tahun di antara kabupaten di Sumatera Utara yang diperoleh melalui Badan Pusat Statistik (BPS) Provinsi Sumatera Utara. Dengan demikian terpilih 5 (lima) kabupaten dengan produksi jagung per tahun tertinggi yaitu kabupaten Karo, kabupaten Dairi, kabupaten Simalungun, kabupaten Langkat dan kabupaten Deli Serdang. Untuk masing- masing kabupaten dipilih 3 kecamatan dengan kriteria yaitu kecamatan dengan produksi tertinggi, sedang dan rendah. Sampel diambil dari 3 level rantaian produksi jagung yaitu petani, pengumpul, pedagang atau pengecer. Dari setiap kecamatan diambil 3 petani, 2 pengumpul, dan 2 pedagang total sampel berjumlah 105 sampel dengan komposisi sampel dari petani 45 sampel, pedagang atau pengecer 30 sampel dan pengumpul 30 sampel. Teknik pengambilan sampel menggunakan metode pengambilan contoh padatan menurut SNI 19- 0428-1998 yang dibedakan untuk sampel dalam hamparan dan sampel dalam karung kemasan.

\section{Pemeriksaan sampel}

Sampel yang diperoleh selanjutnya akan diuji di laboratorium dengan metode yang berbeda untuk setiap variabel yang diuji. Penentuan kadar air dilakukan dengan alat Moisture Tester Burrows DMC500, penentuan kadar protein kasar dilakukan dengan menggunakan alat kjedatherm, penentuan kadar lemak kasar dilakukan dengan alat Soxtherm 416, pengujian kadar serat kasar dilakukan dengan menggunakan alat Fibretherm, sedangkan pengujian kadar aflatoksin, fumonisin, dan zearalenone dilakukan dengan metode LFIA (Lateral Flow Immunochromatic Assay) dan alat Reveal Q.

\section{Analisis data}

Analisa statistik dengan metode analisa korelasi dan regresi menggunakan SPSS versi 21.0 digunakanuntuk untuk mengukur pengaruh varietas, lahan tanam, ketinggian, kelembaban relatif, pengeringan, lama penyimpanan, dan tempat penyimpanan terhadap kadar air, protein kasar, lemak kasar, serat kasar dan kandungan aflatoksin, fumonisin dan zearalenone serta mengukur korelasi antara kadar air, protein kasar, lemak kasar dan serat kasar dengan kadar aflatoksin, fumonisin dan zearalenone.

\section{HASIL DAN PEMBAHASAN}

Pada penelitian ini wawancara dilakukan pada 45 orang petani, 30 orang pedagang dan 30 orang pengumpul jagung di kabupaten Karo, kabupaten Dairi, kabupaten Simalungun, kabupaten Langkat dan kabupaten Deli Serdang. Berdasarkan wawancara yang dilakukan diketahui bahwa responden petani menggunakan benih jagung hibrida dengan kondisi lahan yang kering sehingga menyebabkan penanaman dimulai pada saat musim hujan tiba (Tabel 1). Sistem pemanenan jagung yang diamati adalah petik kering (100\% dari responden), dimana responden memetik jagung pada saat matang sempurna. Pemetikan buah yang kering merupakan salah satu rekomendasi FAO (2001) dalam mencegah kontaminasi mikotoksin di tingkat petani pada saat panen. Sistem pengeringan jagung ditingkat responden petani hanya mengandalkan sinar matahari dimana kadar air rata-rata pada jagung petani adalah 20,4 $\%$ tidak mencapai kadar air aman yakni dibawah 14\%, kadar air yang tidak aman (di atas 14\%) ini sangat beresiko terserang cendawan apalagi tempat penyimpan mengunakan karung goni $(100 \%$ dari responden). Bentuk kerusakan jagung yang banyak ditemukan responden pada saat panen adalah perubahan warna biji, biji berlubang, biji jarang dan berjamur. Bentuk kerusakan ini merupakan peluang cendawan masuk dalam biji jagung dan berkembang biak. 
Tabel 4. Budi daya jagung oleh petani

\begin{tabular}{|c|c|c|c|c|c|}
\hline \multirow{2}{*}{ Materi } & \multicolumn{5}{|c|}{ Responden (\%) } \\
\hline & 1 & 2 & 3 & 4 & 5 \\
\hline \multicolumn{6}{|l|}{ Varietas jagung yang ditanam: } \\
\hline a. Lokal & 0 & 0 & 0 & 0 & 0 \\
\hline b. Komposit & 0 & 0 & 0 & 0 & 0 \\
\hline c. Hibrida & 100 & 100 & 100 & 100 & 100 \\
\hline \multicolumn{6}{|l|}{ Jenis lahan: } \\
\hline a. Lahan kering & 100 & 44 & 100 & 100 & 44 \\
\hline b. Lahan basah & 0 & 56 & 0 & 0 & 56 \\
\hline \multicolumn{6}{|l|}{ Pola tanam: } \\
\hline a. $1 \mathrm{kali} / \mathrm{tahun}$ & 100 & 44 & 100 & 100 & 44 \\
\hline b. 2 kali/tahun & 0 & 44 & 0 & 0 & 56 \\
\hline c. $3 \mathrm{kali} / \mathrm{tahun}$ & 0 & 12 & 0 & 0 & 0 \\
\hline d. 4 kali/tahun & 0 & 0 & 0 & 0 & 0 \\
\hline \multicolumn{6}{|l|}{ Tanda buah matang: } \\
\hline a. Warna klobot & 0 & 0 & 0 & 0 & 0 \\
\hline b. Permukaan biji & 0 & 0 & 0 & 0 & 0 \\
\hline c. Daun dan rambut jagung kering & 44 & 33 & 22 & 67 & 33 \\
\hline d. Jumlah hari & 56 & 67 & 78 & 33 & 67 \\
\hline \multicolumn{6}{|l|}{ Sistem pemetikan: } \\
\hline a. Petik segar & 0 & 0 & 0 & 0 & 0 \\
\hline b. Petik kering & 100 & 100 & 100 & 100 & 100 \\
\hline \multicolumn{6}{|l|}{ Ditemukan jagung rusak saat panen: } \\
\hline a. Ya & 100 & 1000 & 100 & 1000 & 100 \\
\hline b. Tidak & 0 & 0 & 0 & 0 & 0 \\
\hline c. Kadang-kadang & 0 & 0 & 0 & 0 & 0 \\
\hline \multicolumn{6}{|l|}{ Sumber panas pengeringan: } \\
\hline a. Sinar matahari & 1000 & 100 & 100 & 1000 & 100 \\
\hline b. Dryer (alat pengering) & 0 & 0 & 0 & 0 & 0 \\
\hline
\end{tabular}

Keterangan: Jumlah responden $=45$ orang pedagang jagung. Responden: $1=$ Kabupaten Deli Serdang; 2 = Kabupaten Dairi; 3 = Kabupaten Karo; 4 = Kabupaten Langkat; 5 = Kabupaten Simalungun.

Berdasarkan wawancara yang dilakukan diketahui bahwa seluruh responden pedagang jagung langsung membeli jagung dari petani di kelima kabupaten. Bentuk jagung yang dibeli oleh responden hanya dalam bentuk pipil kering (Tabel 2). Semua responden tidak menggunakan alat ukur kadar air dalam pembelian. Dalam menentukan kadar air, responden menggunakan perabaaan atau genggaman tangan sehingga hasilnya tidak akurat. Semua responden pedagang (100\% dari responden) melakukan sortasi, pengeringan, dan penyimpanan. Pengeringan yang dilakukan oleh semua responden pedagang dengan menggunakan sumber panas dari sinar matahari Tiap kabupaten memiliki lama pengeringan yang variasi, antara lain 1-3 hari dan 4-7 hari.

Responden pengumpul yang diwawancarai di lima kabupaten membeli jagung dari petani dan pedagang. Bentuk jagung yang dibeli oleh responden dalam bentuk pipil kering dan tebasan. Responden pengumpul di kabupaten Dairi dan Langkat semua responden membeli jagung dalam bentuk pipil kering, berbeda dengan responden pengumpul di kabupaten Deli Serdang, Karo dan Simalungun (Tabel 3). Di kabupaten Dairi, seluruh responden pengumpul tidak menggunakan alat ukur kadar air dalam membeli jagung. Kemungkinan dalam menentukan kadar air digunakan sistem perabaaan atau genggaman tangan, sehingga hasilnya tidak akurat. 
Tabel 2. Sistem pembelian pedagang

\begin{tabular}{lccccc}
\multicolumn{1}{c}{ Materi } & \multicolumn{5}{c}{ Responden (\%) } \\
\cline { 2 - 7 } & 1 & 2 & 3 & 4 & 5 \\
\hline Jagung yang dibeli dalam bentuk: & & & & & \\
$\quad$ a. Tebasan & 0 & 0 & 0 & 0 & 0 \\
$\quad$ b. Jagung utuh & 0 & 0 & 0 & 0 & 0 \\
$\quad \begin{array}{l}\text { c. Pipil setengah kering } \\
\text { d. Pipil kering }\end{array}$ & 0 & 0 & 0 & 0 & 0 \\
\hline Apakah saat membeli jagung membawa alat & 100 & 100 & 100 & 100 & 100 \\
penguji kadar air & & & & & \\
$\quad$ a. Ya & 0 & 0 & 0 & 0 & 0 \\
$\quad$ b. Tidak & 100 & 100 & 100 & 100 & 100 \\
\hline Dalam pembelian ditemukan jagung yang rusak & & & & & \\
$\quad$ a. Ya & 100 & 100 & 100 & 100 & 100 \\
b. Tidak & 0 & 0 & 0 & 0 & 0 \\
$\quad$ c. Kadang-kadang & 0 & 0 & 0 & 0 & 0 \\
\hline
\end{tabular}

Melakukan sortasi/pemisahan terhadap kualitas jagung:

\begin{tabular}{lccccc} 
a. Ya & 100 & 100 & 100 & 100 & 100 \\
b. Tidak & 0 & 0 & 0 & 0 & 0 \\
\hline Sumber panas pengeringan: & & & & & \\
a. Sinar matahari & 100 & 100 & 100 & 100 & 100 \\
b. Dryer (alat pengering) & 0 & 0 & 0 & 0 & 0 \\
\hline Lama pengeringan: & & & & & \\
a. $1-3$ hari & 83 & 16 & 67 & 100 & 67 \\
b. $4-7$ hari & 17 & 84 & 33 & 0 & 33 \\
c. $8-10$ hari & 0 & 0 & 0 & 0 & 0 \\
d. $>10$ hari & 0 & 0 & 0 & 0 & 0 \\
\hline
\end{tabular}

Tempat penyimpanan :

\begin{tabular}{lccccc} 
a. Hamparan di atas tanah & 0 & 0 & 0 & 0 & 0 \\
b. Dalam karung atau goni & 100 & 100 & 100 & 100 & 100 \\
c. Hamparan di atas lantai semen & 0 & 0 & 0 & 0 & 0 \\
d. Hamparan di atas terpal & 0 & 0 & 0 & 0 & 0 \\
\hline
\end{tabular}

Mengenal Mikotoksin atau jamuran:

\begin{tabular}{lccccc} 
a. Ya & 100 & 84 & 100 & 100 & 100 \\
b. Tidak & 0 & 16 & 0 & 0 & 0 \\
\hline
\end{tabular}

Pangsa Pasar:
a. Pedagang Besar
$\begin{array}{lllll}0 & 0 & 0 & 0 & 0\end{array}$
b. Peternak
$\begin{array}{lllll}100 & 84 & 67 & 100 & 100\end{array}$
e. Pabrik Pakan Ternak

$\begin{array}{lllll}0 & 16 & 33 & 0 & 0\end{array}$

Keterangan: Jumlah responden $=30$ orang pedagang jagung. Responden: $1=$ Kabupaten Deli Serdang; 2 = Kabupaten Dairi; 3 = Kabupaten Karo; $4=$ Kabupaten Langkat; 5 = Kabupaten Simalungun. 
Tabel 3. Sistem pembelian pengumpul jagung

\begin{tabular}{|c|c|c|c|c|c|}
\hline \multirow{2}{*}{ Materi } & \multicolumn{5}{|c|}{ Responden (\%) } \\
\hline & 1 & 2 & 3 & 4 & 5 \\
\hline \multicolumn{6}{|l|}{ Jagung yang dibeli dalam bentuk: } \\
\hline a. Tebasan & 17 & 0 & 33 & 0 & 17 \\
\hline b. Jagung utuh & 0 & 0 & 0 & 0 & 0 \\
\hline c. Pipil setengah kering & 0 & 0 & 0 & 0 & 0 \\
\hline d. Pipil kering & 83 & 100 & 67 & 100 & 83 \\
\hline
\end{tabular}

Apakah saat membeli jagung membawa alat penguii kadar air

\begin{tabular}{lccccc} 
a. Ya & 50 & 0 & 33 & 33 & 17 \\
b. Tidak & 50 & 100 & 67 & 67 & 83 \\
\hline Dalam pembelian ditemukan jagung yang rusak: & & & & & \\
a. Ya & 100 & 100 & 100 & 100 & 100 \\
b. Tidak & 0 & 0 & 0 & 0 & 0 \\
c. Kadang-kadang & 0 & 0 & 0 & 0 & 0 \\
\hline
\end{tabular}

Melakukan sortasi/pemisahan terhadap kualitas jagung:

\begin{tabular}{lccccc} 
a. Ya & 100 & 100 & 100 & 100 & 100 \\
b. Tidak & 0 & 0 & 0 & 0 & 0 \\
\hline umber panas pengeringan: & & & & & \\
a. Sinar matahari & 83 & 100 & 100 & 50 & 100 \\
b. Dryer (alat pengering) & 17 & 0 & 0 & 50 & 0 \\
\hline
\end{tabular}

Lama pengeringan:

\begin{tabular}{lccccc} 
a. $1-3$ hari & 13 & 0 & 17 & 33 & 33 \\
b. $4-7$ hari & 67 & 100 & 83 & 67 & 67 \\
c. 8 - 10 hari & 0 & 0 & 0 & 0 & 0 \\
d. $>10$ hari & 0 & 0 & 0 & 0 & 0 \\
\hline
\end{tabular}

Tempat penyimpanan :

a. Hamparan di atas tanah

b. Dalam karung atau goni

$\begin{array}{lllll}0 & 0 & 0 & 0 & 0\end{array}$

c. Hamparan di atas lantai semen

$\begin{array}{lllll}100 & 100 & 100 & 100 & 100\end{array}$

d. Hamparan di atas terpal

$\begin{array}{lllll}0 & 0 & 0 & 0 & 0\end{array}$

Mengenal Mikotoksin atau jamuran:
a. Ya
$\begin{array}{lllll}100 & 100 & 100 & 100 & 100\end{array}$
b. Tidak

$\begin{array}{lllll}0 & 0 & 0 & 0 & 0\end{array}$

Pangsa Pasar:
a. Pedagang Besar
b. Peternak
$\begin{array}{lllll}0 & 0 & 0 & 0 & 0\end{array}$
$\begin{array}{lllll}67 & 100 & 67 & 83 & 50\end{array}$
e. Industri Pakan Ternak

$\begin{array}{lllll}33 & 0 & 33 & 17 & 50\end{array}$

Keterangan: Jumlah responden $=30$ orang pedagang jagung. Responden: $1=$ Kabupaten Deli Serdang; 2 = Kabupaten Dairi; 3 = Kabupaten Karo; 4 = Kabupaten Langkat; 5 = Kabupaten Simalungun.

Berbeda dengan pengumpul di kabupaten Deli Serdang, Karo, Langkat dan Simalungun yang sebagian pengumpulnya mengunakan alat pengukur kadar air. Banyaknya peternak/farm dan industri pakan ternak di Deli Serdang, Karo, Simalungun dan Langkat yang memiliki sistem penerimaan jagung yang berstandar menyebabkan pengumpul harus memastikan kadar air jagung yang akan mereka jual ke peternak/farm maupun industri pakan ternak.

Pada penelitian ini, dilakukan pengujian terhadap variabel terikat yaitu 
yaitu kadar air, protein kasar, lemak kasar, dan serat kasar juga kandungan mikotoksin, yaitu aflatoksin, fumonisin, dan zearalenone dari sampel jagung yang dikumpulkan. Berdasarkan pengujian yang dilakukan diketahui bahwa nilai kadar air jagung berada di atas nilai persyaratan kadar air maksimum dalam jagung yaitu $>14 \%$ (Tabel 4). Kadar air panen rata-rata biji jagung adalah $20 \%$ namun bila daerah penanaman adalah daerah kering biasanya kadar air panen biji bisa mencapai $17 \%$. Selanjutnya biji jagung dikeringkan untuk mengurangi kadar air bahan hingga mencapai kadar air kesetimbangan (Khalil dan Anwar, 2006). Menurut FAO (2001) jagung pipil kuning dengan kadar air $<16 \%$ akan mempunyai umur simpan selama 1 bulan, pada kadar air <14\% mempunyai umur simpan sekitar 3 bulan, dan jika kadar air $<12 \%$ umur simpan jagung akan mencapai 3 tahun. Dalam penelitian, hanya ditemukan kadar air $>16 \%$ sehingga responden hanya menyimpan jagung paling lama sampai 10 hari saja. Karena semakin lama waktu penyimpanan, maka kadar air akan semakin meningkat. Dengan kadar air $14 \%$ atau kurang umumnya bahan pangan dapat disimpan dalam keadaan segar dan kering cukup lama di dalam tempat penyimpanan yang kering (Arsyad, 2018).

Kadar protein kasar sampel jagung masih memenuhi persyaratan SNI 01-44831998 yaitu $>7.5 \%$ (Tabel 4), ini kemungkinan disebabkan karena umur panen yang sama yaitu sekitar pada umur 4 bulan (120 hari). Hal ini sesuai dengan pendapat (Karimuna et al., 2009), bahwa kadar protein akan menurun dengan semakin tuanya umur tanaman.

Tabel 4. Kadar minimum, maksimum, dan rata-rata dari nutrisi dan mikotoksin jagung

\begin{tabular}{lccc}
\hline \multicolumn{1}{c}{ Variabel } & Minimum & Maksimum & Rata-Rata \\
\hline Kadar Air & 16.20 & 23.30 & 19.33 \\
\hline Kadar Protein Kasar & 7.11 & 9.97 & 8.52 \\
\hline Kadar Lemak Kasar & 2.92 & 4.13 & 3.38 \\
\hline Kadar Serat Kasar & 1.78 & 2.98 & 2.35 \\
\hline Kandungan Aflatoksin & 2.60 & 58.70 & 18.72 \\
\hline Kandungan Fumonisin & 0.30 & 0.90 & 0.44 \\
\hline Kandungan Zearalenone & 50 & 60 & 52.48 \\
\hline
\end{tabular}

Nilai rata-rata kadar lemak kasar sampel jagung masih memenuhi persyaratan SNI yaitu $>3.0 \%$ (Tabel 4 ). Hal ini mungkin disebabakan karena jagung ditanam di daerah kering yang bersuhu tinggi. Suhu tinggi akan meningkatkan ketebalan batang dengan pertumbuhan yang baik dari xylem dan menyebabkan jaringan internode cepat berkembang sehingga kandungan serat kasar tinggi (Aulia et al., 2017).

Kandungan aflatoksin rata-rata sampel jagung secara umum juga masih memenuhi persyaratan SNI 01-4483-1998 yaitu < 50 ppb meskipun ada beberapa sampel yang melebihi ambang batas tersebut, Nilai rata- rata kandungan fumonisin dalam sampel jagung berada di bawah standar SNI tahun 2009 yaitu berkisar 2 ppm. Sampel jagung yang diuji memiliki kandungan zearalenone namun belum ada SNI yang menyebutkan batas maksimal zearalenone pada jagung. Dalam perdagangan internasional, batas maksimum zearalenone belum dipersyaratkan, namun ada delapan Negara yang memiliki peraturan khusus terhadap batas maksimal kandungan zearalenone yang berkisar 30-1000 ppb (Surono, 2018). Kondisi lingkungan terutama suhu dan kelembaban relatif selama musim tanam merupakan faktor yang mempengaruhi terjadinya kontaminasi mikotoksin pada 
jagung. Kadar mikotoksin yang rendah kemungkinan besar didukung oleh adanya upaya perbaikan yang cukup efektif dalam hal produksi dan cara bercocok tanam yang merupakan faktor penting yang perlu diperhatikan dalam menghindari kontaminasi mikotoksin pada jagung (Widiastuti, 2006).

Secara statistik terlihat bahwa secara serempak, faktor varietas, lahan tanam, ketinggian, kelembaban relatif, sumber pengeringan, lama penyimpanan, dan tempat penyimpanan berpengaruh sangat signifikan terhadap kadar air, protein kasar, lemak kasar, serat kasar, kandungan aflatoksin, fumonisin, dan zearalenone (Tabel 5). Hal ini sejalan dengan pernyataan Martindah dan Bahri (2016) bahwa beberapa faktor yang dapat mempengaruhi sifat dan kuantitas mikotoksin pada jagung adalah jenis substrat, kadar air, nutrisi yang tersedia, suhu, kelembaban di lingkungan sekitarnya, kematangan koloni jamur, keberadaan dan persaingan dengan kapang atau dari mikroorganisme lain, kerusakan fisik dari substrat akibat aktivitas serangga, serta faktor stress. Tersedianya faktorfaktor tersebut akan mendukung pertumbuhan kapang pada jagung. Dnegan meningkatnya pertumbuhan kapang pada jagung maka kadar mikotoksin yang dihasilkan juga akan meningkat dan secara langsung akan mempengaruhi nilai kandungan mikotoksin jagung.

Tabel 5. Nilai F hitung dan signifikansi dari pengaruh varietas, lahan tanam, ketinggian, kelembaban relatif, sumber pengeringan, lama penyimpanan, dan tempat penyimpanan terhadap nutrisi (kadar air, kadar protein kasar, kadar lemak kasar dan kadar serat kasar) dan mikotoksin (Aflatoksin, Fumonisin dan Zearalenone)

\begin{tabular}{lcl}
\hline \multicolumn{1}{c}{ Variabel } & F & Sig. \\
\hline Kadar Air & 3.378 & $0.003^{*}$ \\
Kadar Protein Kasar & 2.294 & $0.033^{*}$ \\
Kadar Lemak Kasar & 2.423 & $0.025^{*}$ \\
Kadar Serat Kasar & 2.475 & $0.022^{*}$ \\
Kandungan Aflatoksin & 5.748 & $0.000^{*}$ \\
Kandungan Fumonisin & 5.649 & $0.000^{*}$ \\
Kandungan Zearalenone & 2.462 & $0.023^{*}$ \\
\hline
\end{tabular}

Keterangan: *nilai signifikan pada selang kepercayaan $95 \%$

Berdasarkan analisis statistik diketahui bahwa kelembaban relatif dan lama penyimpanan berpegaruh signifikan terhadap kadar aflatoksin jagung, sedangkan lahan tanam dan kelembabab relatif berpengaruh signifikan terhadap kandungan fumonisin. Pada kandungan zearalenone, tidak ada variabel yang berpengaruh signifikansi terhadap kandungan zearalenone (Tabel 6).

Tabel 6. Nilai signifikansi kandungan mikotoksin terhadap kadar air, kadar protein kasar, kadar lemak kasar dan kadar serat kasar

\begin{tabular}{lccc}
\hline \multirow{2}{*}{ Variabel } & \multicolumn{3}{c}{ Nilai Signifikansi } \\
\cline { 2 - 4 } & Aflatoksin & Fumonisin & Zearalenone \\
\hline Varietas & 0.968 & 0.855 & 0.094 \\
Lahan Tanam & 0.422 & $0.302^{*}$ & 0.997 \\
Ketinggian & 0.295 & 0.080 & 0.094 \\
Kelembaban Relatif & $0.000^{*}$ & $0.000^{*}$ & 0.287 \\
Sumber Pengeringan & 0.975 & 0.768 & 0.227 \\
Lama Penyimpanan & $0.005^{*}$ & 0.244 & 0.085 \\
Tempat Penyimpanan & 0.157 & 0.128 & 0.380 \\
\hline
\end{tabular}

Keterangan: *nilai signifikan pada selang kepercayaan $95 \%$. 
Kelembaban relatif dan lama penyimpanan berpegaruh signifikan terhadap kadar aflatoksin jagung. Hal ini didukung oleh pernyataan Hedayati et al. (2007) yang mengatakan bahwa kondisi lingkungan terutama suhu dan kelembaban relatif selama musim tanam merupakan faktor yang mempengaruhi terjadinya kontaminasi aflatoksin pada jagung. Menurut Hidayah et al., (2018) suhu optimum dan waktu yang dibutuhkan untuk memproduksi aflatoksin oleh A. flavus adalah $25^{\circ} \mathrm{C}$ dalam waktu 7- 9 hari, suhu $30^{\circ} \mathrm{C}$ dalam waktu 5-7 hari dan pada suhu $20^{\circ} \mathrm{C}$ dibutuhkan waktu 11- 13 hari. Sehingga apabila jagung diletakkan dalam tempat yang memiliki kelembaban tinggi dalam waktu yang lama dapat meningkatkan kadar aflatoksin pada jagung.

Lahan tanam dan kelembaban relatif secara statistik berpengaruh signifikan padad kadar fumonisin jagung. Hal ini didukung oleh pernyataan Surono (2018) yang menyatakan bahwa fumonisin pada jagung dapat dihasilkan pada saat di ladang juga selama penyimpanan, terutama apabila kondisi lembab saat dipanen dan tidak benar kering sebelum penyimpanan. Kondisi lahan tanam dan kelembaban yang tinggi pada saat masa tanam jagung di area yang diamati menyebabkan tumbuhnya kapang yang menghasilkan mikotoksin zearalenone pada jagung dan menyebabkan jagung tercemar oleh mikotoksin tersebut.

Zearalenone adalah mikotoksin estrogenic nonsteroid yang diduga bersifat karsinogenik. Zearalenone dihasilkan oleh beberapa spesies Fusarium sp. yang banyak ditemukan di seluruh dunia dalam produkproduk serealia, seperti jagung. Zaearalenon umumnya bersifat estrogenik pada hewan ternak, yang meliputi penurunan produksi, gangguan reproduksi, dan penyempitan ovarium (Azam et al., 2019). Fusarium dapat memproduksi zearalenone dalam jumlah tertinggi apabila ada pada lingkungan dengan suhu dibawah $25^{\circ} \mathrm{C}$ dan kelembaban $16 \%$
(Zwierzchowski et al., 2005). Faktor ini lah yang merupakan faktor yang paling penting mengenai keberadaan kandungan zearalenone pada jagung. Hal ini juga kemungkinan merupakan alasan mengenai tidak signifikannya pengaruh varietas jagung, lahan tanam, ketinggian, kelembaban relatif, sumber pengeringan, lama penyimpanan, dan tempat penyimpanan terhadap kadar zearalenone jagung di kabupaten yang diamati.

\section{SIMPULAN DAN SARAN}

\section{Simpulan}

Berdasarkan penelitian yang dilakukan, maka dapat disimpulkan bahwa faktor ketinggian dan lama penyimpanan berpengaruh signifikan terhadap kadar air serta faktor ketinggian berpengaruh signifikan terhadap kadar serat kasar. Sedangkan pada kadar protein kasar dan kadar lemak kasar tidak dipengaruhi oleh kadar air, kadar protein kasar, kadar lemak kasar dan kadar serat kasar Faktor kelembaban relatif dan lama penyimpanan berpengaruh secara signifikan terhadap kandungan aflatoksin. Faktor kelembaban relatif berpengaruh secara signifikan terhadap kandungan fumonisin. Sedangkan, kandungan zearalenone tidak dipengaruhi oleh kadar air, kadar protein kasar, kadar lemak kasar dan kadar serat kasar.

\section{Saran}

Diharapkan dapat ditingkatkan kesadaran tentang pentingnya meningkatkan metode penyiapan jagung yang bebas kontaminasi mikotoksin kepada konsumen, petani, dan pedagang. Selain itu, diperlukan program monitoring dan pemeriksaan sehingga menghasilkan banyak data tentang distribusi dan tingkat kontaminasi aflatoksin pada jagung yang beredar. Untuk mendapatkan jagung dengan kadar mikotoksin yang rendah, pengeringan jagung dilakukan di tingkat petani, pedagang dan pengumpul harus secepat mungkin dan mencapai kadar air yang aman yakni dibawah $14 \%$. 
Penyuluhan tentang mikotoksin dan teknik pengendaliannya perlu dilakukan terutama bagi petani, pedagang dan pengumpul. Tercapainya usaha menekan mikotoksin didalam bahan baku jagung dibutuhkan adanya komitmen bersama dari semua stakeholders.

\section{UCAPAN TERIMAKASIH}

Ucapan terima kasih kepada ketua Program Studi Ilmu Peternakan Program Pascasarjana Fakultas Pertanian Universitas Sumatera Utara serta semua pihak yang telah membantu dalam menyelesaikan peneitian ini.

\section{DAFTAR PUSTAKA}

Arsyad M. 2018. Pengaruh pengeringan terhadap laju penurunan kadar air dan berat jagung (Zea Mays L.) untuk varietas bisi 2 dan NK22. J. Agropolitan, 5(1): 44-52.

Aulia F, Erwanto, Wijaya AK. 2017. Pengaruh umur pemotongan terhadap kadar air, abu dan lemak kasar Indigofera zollingeriana. $J . \quad$ Riset Inovasi Peternakan, 1(3): 1-4.

Azam MS, Yu D, Liu N, Wu A. 2019. Degrading ochratoxin a and zearalenone mycotoxins using a multifunctional recombinant enzyme. Toxins, 11(5): 301-323.

Food and Agriculture Organization (FAO). 2001. Manual on the Application of the HACCP System in Mycotoxin Prevention and Control. http:// www. fao. org/docrep/005/y1390e00.HTM.

Hedayati MT, Pasqualotto AC, Warn PA, Bowyer P, Denning DW. 2007. Aspergillus flavus: Human pathogen, allergen and mycotoxin producer. $J$. Microbiol., 153(6): 1677 - 1692.

Hidayah I, Hermana I, Kusmarwati A. 2018. Risk profile and semi quantitative risk probability of aflatoxin b1 from aspergillus flavus in a dried salted fish in several regions of java. Squalen Bull.
Mar. Fish. Postharvest. Biotech., 13(2): 85-91.

Hidayat C. 2012. Pengembangan produksi ayam lokal berbasis bahan pangan lokal. Wartazoa, 22(2): 85-98.

Ilhamy ML, Pratiwi S. 2018. Strategi pemberdayaan UMKM sektor peternakan ayam organik (Studi pada Koperasi Hidayah Sumatera Utara). Human Falah, 5(2): 293-312.

Karimuna L, Safitri, Sabaruddin LO. 2009. Pengaruh jarak tanam dan pemangkasan terhadap kualitas silase dua varietas jagung (Zea mays L.). Agripet., 9(1): 17-25.

Karra. 2003. Ilmu Makanan Ternak Dasar. Gajah Mada University. Jogjakarta.

Khalil, Anwar S. 2006. Penanganan pascapanen dan kualitas jagung sebagai bahan pakan di Kabupaten Pasaman Barat. J. Peternakan Indonesia, 11(1): 36-45.

Martindah E, Bahri S. 2016. Kontaminasi mikotoksin pada rantai makanan. Wartazoa, 26(3): 115-124.

Miskiyah, Widaningrum. 2008. Pengendalian aflatoksin pada pascapanen jagung melalui penerapan HACCP. J. Standardisasi, 10(1): 1 10.

Surono IS, Sudibyo A, Waspodo P. 2018. Pengantar Keamanan Pangan untuk Industri Pangan. Yogyakarta: Deepubllish.

Widiastuti R. 2006. Mikotoksin: pengaruh terhadap kesehatan ternak dan residunya dalam produk ternak serta pengendaliannya. Wartazoa, 16(3): 116-127.

Zwierzchowski W, Przybylowicz M, Obremski K, Zielonka L, SkorskaWyszynska E, Gajecka M, Polak M, Jakimiuk E, Jana B, Rybarczyk, L, Gajecki M. 2005. Level of zearalenone in blood serum and lesions in ovarian follicles of sexually immature gilts in the course of zearalenone micotoxicosis. Polish J. Vet. Sci., 8: 209-218. 